\title{
Children's Attributions and Emotions for Their Friendships With Their Best Friend
}

\author{
Georgia Stephanou \\ University of Western Macedonia, Florina, Greece
}

\author{
Konstantina Balkamou \\ Hellenic Open University, Patra, Greece
}

\begin{abstract}
This study, basing on the connection between close relationships and emotional experience from a socio-cognitive perspective, mainly attribution theories, aimed to examine: (1) children's attributions and emotions for their subjectively perceived positive and negative friendships with their best friend; (2) if children's attributions and emotions are differentiated depending on whether they perceive their friendship as positive or negative; and (3) the role of the attributional and intuitive (perceived quality) appraisals of the friendship in the formation of the emotions, and in the impact of the emotions on expectations about the quality of the friendship. A total of 225 children, both genders, third and fourth grades, participated in this investigation. All the participants, after writing down the name of their best friend, completed, first, the scale of emotions and, then, the scales of attributions and expectations. The results showed that the perceived positive friendships were mainly attributed to companionship-recreation and perceived help and support by the friends as well as to internal, stable, personal controllable, external uncontrollable and self-friend interactive internal factors. In contrast, the main attributions for the perceived negative friendships were non-exclusiveness, lack of companionship-recreation and friends' bad character as well as friends' controllable and internal, personally uncontrollable, external and unstable factors. Also, the participants experienced intense positive and negative emotions (particularly, friendship- and future- related) for the positive and negative friendships, respectively. Attribution (mainly, stability), compared to intuitive appraisal of friendship, was a better predictor of most of the emotions in the negative friendships group, while the pattern was reversed in the positive friendships group. Finally, emotions, attributions (not in negative friendships) and intuitive appraisal uniquely contributed into the generation of friendship expectations. Discussion of the findings focuses on enhancing children's subjective well-being and on future research.
\end{abstract}

Keywords: attributions, emotions, expectations, friendship

\section{Introduction}

Youth co-operation with peers and close friendship are related to enduring happiness and well-being (Argyle, 2001; Berndt, 2004; Carr, 2005; Holder \& Coleman, 2009; Vandell, Nenide, \& Van Winkle, 2007). Understanding children's perceptions of their friendships, in particular, may contribute to understanding their emotional lives and development, since happy young people are those who report fulfilling friendships (Bukowski, 2001; Buss, 2005; Diener, 2000; Diener \& Seligman, 2002; Flecher \& Thomas, 1996; Hoglund, Lalonde, \& Leadbeater, 2008). Furthermore, focusing on children's friendships with their best friends may help 
enhancing their happiness and subjective well-being, as positive psychology conceptualizes (Aspinwall \& Staudinger, 2003; Diener, Lucas, \& Oishi, 2005; Myers, 2000; Roberts, Brown, Johnson, \& Reinke, 2005; Seligman, 2002, 2005).

Cognition and cognitive process are significant contributors in the development and quality of a close relationship, and so need to be examined in any comprehensive research of friendship (Blas, 2007; Harvey, Pauwels, \& Zickmund, 2005; Karney, McNulty, \& Bradbury, 2003). Specifically, intuitive and atributional appraisals have been central concepts in the research in close relationships (Collins, Ford, Guichard, \& Allard, 2006; Fincham, 2003; Greitemeyer \& Weiner, 2003; Harvey, 1987; Harvey \& Omarzu, 1999; Prager, 1995; Reis \& Patrick, 1996; Stephanou, 2004, 2005; Weiner, 2000). Whether partners perceive their relationship as positive or negative, and which explanations or interpretations they make about the relationship influence their emotions, motivation and behaviour (Blascovich \& Mandess, 2000; Flecher, Fitness, \& Blampied, 1990; Flecher $\&$ Thomas, 2000; Fincham, 2003; Fincham, Beach, Arias, \& Brody, 1998; Fitness, Fletcher, \& Overall, 2005).

Concerning the emotions, more precisely, the attributional appraisal perspective focuses on how specific emotions, such as sadness and anger are formulated in a certain relationship, and on their motivational consequences in the relationship (Clore \& Ortony, 2010; Frijda, 1993, 2007; Smith \& Kirby, 2000; Weiner, 2002, 2005). For example, if one believes that the friend's good behaviour was the significant factor for their good friendship, then she/he may experience admiration or gratitude. Anger combines distress over an undesired event with perceiving the other as responsible for it (Ortony, Clore, \& Collins, 1988). Once emotions are experienced, they influence partners' on-going appraisals, perceptions, information processing with important consequences in relationship judgments and behaviours (Bless, 2003; Forgas, 1995; Parrott, 2003; Weiner, 2006). For example, happy partners make more optimistic attributions than unhappy (Forgas, 1994; Planalp \& Fitness, 1999). Anger pushes individuals to attribute blame and malicious intentions to others (Fitness \& Fletcher, 1993; Keltner, Ellsworth, \& Edwards, 1993).

Yet, emotions are inherently and intensely experienced in the context of close relationships with significant effects on partners' future behaviour, and on the development of the relationship, and so are needed to be included in any comprehensive discussion (Fehr \& Harasymchuk, 2005; Baucom, Epstein, \& Stanton, 2006; Berscheid \& Ammazzalorso, 2003; Forgas, 2002; Forgas \& Smith, 2005; Parrott, 2003; Rose, 2007; Siemer, Mauss, \& Gross, 2007; Smith \& Kirby, 2000).

Also, as the friendship develops, the friends are forming expectations for a series of constructs in the friendship, such as the friend dispositional behaviour and the content of the friendship. Literature in the person's perception and cognition underlines that the dispositional attributions an individual makes to the partner reflect expectations of how he/she will behave in various situations (Berscheid \& Ammazzalorso, 2003; Karney et al., 2003; Trope \& Gaunt, 2005). The expectations we hold about our friend and the friendship are partly constructed through the cognitive appraisals we make and the emotions we experience in the friendship (Bigelow, 1997; Forgas \& Smith, 2005; Stephanou, 2007, 2010). Similar are the findings from research in achievement behaviour showing the high expectations for success are related to task engagement, persistence in carrying out tasks, effective use of cognitive and meta-cognitive strategies and successful performance (Eccles \& Wigfield, 2002; Efklides, 2001; Stephanou, 2008).

Finally, the meaning, the content and the perceptions about friendship differ across ages (Erdley, Nangle, Newman, \& Carpenter, 2001; Galanaki, 2003; Gifford-Smith \& Brownell, 2003; Hartup, 1996; Pillow, Lovett, \& Hill, 2008). For example, in early childhood, friends are co-players, while, in middle childhood, friends 
support, communicate and trust each other. Also, children at this age attribute high value to the formulating and maintaining of a friendship, they make interpretations about the quality of their friendship, which influence emotions and motivation, they have expectations about their friendship and they are quite able to regulate their thoughts, emotions and behaviour in the context of their friendship (M. Cole \& S. R. Cole, 2001; Colonnesi, Engelhard, \& Bogels, 2009; Holder \& Coleman, 2009; Hoglund, Lalonde, \& Leadbeater, 2008; Juvonen \& Weiner, 1993; Weiner \& Handel, 1985). Overall, the empirical evidence suggests the necessity of examining friendship through child development.

However, little research has focused on children's friendships (Bukowski, 2001; Gifford-Smith \& Brownell, 2003; Hoglund et al., 2008; Rose, 2007; Vandell et al., 2007). Also, although children's attributions and emotions for their friendships reflect and influence the quality of the friendship, only a limited number of studies have focused on these concepts, and on how they interactively influence friendship expectations (Bowker, Rubin, Burgess, Booth-LaForce, \& Rose-Krasnor, 2006; Fincham, 2003; Jenkins \& Ball, 2000; Lewis \& Kliewer, 1996; Overwalle, Heylighen, Casaer, \& Daniels, 1992; Stephanou, 2010; Underwood \& Hurley, 1999).

Consequently, this study is based on the connection between friendships and emotional experience from a socio-cognitive perspective. Specifically, Weiner's (1992; 2001; 2002) attributions theory was involved, which, incorporating cognitive appraisals and emotions, is helpful in understanding interpersonal relationships (Argyle, 2001; Fincham, 2003; Fitness et al., 2005; Fletcher \& Clark, 2003; Hewstone \& Antaki, 2001).

\section{Attributions and Emotions for Interpersonal Relationships}

The individuals appraise their interpersonal relationships, while the appraisal of a relationship reflects what it means to the individual and whether it is good or bad (Fincham, 2003; Fitness et al., 2005; Leary, 2000; Smith \& Lazarus, 1990; Trope \& Gaunt, 2005).

An interpersonal relationship could be ascribed to infinite number of causes but self, other person, situation, environment, self-other person interaction and relationship itself are the most prominent causes in describing positive and negative relationships (Argyle, 2001; Erber \& Gilmour, 1995; Planalp \& Rivers, 1996). Also, partners tend to attribute their positive interpersonal relationships to themselves and their negative interpersonal relationships to the other person and situational factors (Fiedler, Semin, Finkenauer, \& Berkel, 1995; Fitness et al., 2005; Stephanou, 2005, 2007; Weiner, 2001, 2002; Ybarra \& Stephan, 1999). Furthermore, the more negative the interpersonal relationship, the more the attributions to the other person's constant negative properties (Argyle, 2001; Fincham, 2003; Gilbert \& Malone, 1995; Hewstone \& Antaki, 2001; Williams \& Gilmore, 2008).

Attributions are categorized into causal dimensions of locus of causality (internal/external to the person), stability (stable/unstable over time) and controllability (personal and external controllable/uncontrollable), which have psychological and behavioral consequences (Argyle, 2001; Berscheid \& Ammazzalorso, 2003; Fletcher \& Thomas, 2000; McAuley, Duncan, \& Russell, 1992; Stephanou, 2005, 2007; Weiner, 2002, 2005).

Previous researches show that both intuitive appraisal (how good the relationship is) and the attributional appraisal are major source of the experienced emotions in interpersonal relationships (Clark, Fitness, \& Brissette, 2003; Fletcher, 2002; Smith \& Lazarus, 1990; Trope \& Guant, 2005; Weiner, 2002). According to Weiner's (2002) attribution theory, there are "outcome-dependent" (e.g., happiness, pleasure and sadness) emotions that are the initial and strongest response to the valence of the relationship. For example, if it is 
positive, a person fells happy, whereas if it is negative, he/she fells sad. The "attribution-dependent" (e.g., anger and encouragement) emotions are influenced by the causal explanation for the relationship (Oatley \& Jenkins, 1998; Stephanou, 2007; Weiner, 2002). For example, a child may experience anger if she/he believes that the friend could and should have behaved differently. In contrast, a child may feel confidence if she/he considers the friend's positive dispositional factors as causes for the positive friendship.

Although all causal dimensions are related to emotions for the partner's (friend) behavior and the relationship itself, their prevalence differs across the various emotions. Locus of causality, stability and controllability mainly influence the self-esteem (pride)-expectancy (confidence) and social (shame, anger and gratitude)-related emotions, respectively (Berndsen \& Manstead, 2007; Stephanou, 2007; Weiner, 2005, 2006). For example, internal attributions for successful events (positive friendship) are related to feelings of confidence and pride, whereas external attributions lead to positive behaviors such as help seeking, or negative responses, such as helplessness, avoidance and lack of persistence. In contrast, attributing unsuccessful events (e.g., negative friendship) to internal factors predicts shame, guilt and resignation, whereas attributing unsuccessful events to others causes aggression and vindictiveness (Fincham, 2003; Fitness et al., 2005).

Attributing good friendship to stable factors enhances friendship expectations, and facilitates relationship engagement, while attributing negative friendship to unstable is likely to improve friendship and minimize the feeling of hopelessness. In contrast, attributing negative friendship to stable factors reduces positive expectations, produces the feeling of hopelessness and can lead to learned helplessness, a sense that none effort can lead to good friendship (Fitness et al., 2005; Peterson \& Steen, 2005; Seligman, 2002; Stephanou, 2010; Weiner, 2001). Guilt and anger are elicited by controllable causes, but guilt emerges from internal, whereas anger is typically elicited by external factors (Stephanou, 2007; Weiner, 1992). Hate resulted from appraisals of relative powerlessness and a perceived lack of control (Fitness et al., 2005). Also, stable causes maximize feelings of pity, given uncontrollable causes, and feelings of anger, given controllable causes (Graham \& Hoehn, 1995).

Overall, the belief that a person has about the causes of his/her friendship influences his/her feelings for the friend and his/her expectations for the quality of the friendship in the future (Clark et al., 2003; Fletcher, 2002; Siemer et al., 2007; Weiner, 2001). Then, emotions and expectations influence the individual's actual behavior towards the partner and the friendship itself (Fincham, 2003; Fletcher \& Clark, 2002; Fletcher \& Thomas, 2000; Weiner, 2001).

\section{Aim and Hypotheses of This Study}

This study aimed to examine: (1) children's attributions and emotions for their subjectively perceived positive and negative friendships with their best friend; (2) if children's attributions and emotions are differentiated depending on whether they perceive their friendship as positive or negative; (3) the role of attributional and intuitive (perceived quality) appraisals of the friendships on the $t$ emotions; and (4) the role of the attributional and intuitive appraisals of the friendship in the impact of the emotions on the formulation of expectations of the quality of the friendship in the future.

The hypotheses of the study were the following:

Children will attribute the perceived quality of their friendships with their best friends to various factors (among them, friend, self, friend-self interaction and environment) (Hypothesis 1a). The perceived positive friendships will be attributed to internal, stable, personal controllable and external uncontrollable causes (e.g., 
self-properties), while the perceived negative friendships will be ascribed to external, unstable, external controllable and personal uncontrollable causes (e.g., friend-related) (Hypothesis 1b). Locus of causality, compared to the other attributional dimensions, will be the most powerful dimension in discriminating the two groups of the participants (Hypothesis 1c).

Children will experience positive and negative emotions (mainly, outcome-dependent) for their perceived positive friendships and negative friendships, respectively (Hypothesis 2).

Each attributional dimension will be mainly related to specific kind of emotions, as suggested in attributional theories (Hypothesis 3a). The intuitive appraisal of the friendship and the attributional appraisal of the friendship, compared the one to other, will be a better predictor of the outcome-dependent and attribution-dependent emotions, respectively (Hypothesis 3b).

Both kind of appraisals and emotions for the current quality of the friendship will be positively related to friendship expectations (Hypothesis 4a). Both appraisals (mainly, stability) of the friendship will positively influence the impact of the emotions (particularly, expectancy-related) on the friendship expectations (Hypothesis 4b).

\section{Method}

\section{Participants}

A total of 225 children, both genders, girls $=113$ and boys $=112$, third and fourth grades, participated in this investigation. The children came from various towns from central Greece, representing various parental socioeconomic levels. Of the participants, 185 and 40 estimated their friendships with their best friend as positive and negative, respectively.

\section{Measurements}

The contracture of the scales was based on previous relevant to the topic empirical and theoretical literature (Bowker et al., 2006; Fletcher, 2002; Fincham, 2003; Fincham et al., 1998; Holder \& Coleman, 2009; Stephanou, 2007; Weiner, 2001, 2006) and findings from a pilot research. All scales were in Greek language.

Perceptions of friendship. The children's perceptions of the quality of their friendships with their best friends were examined via a five-point four scale with items (e.g., "How good is this friendship?" and "How much satisfied are you with this friendship?"). Responses ranged from 1 = "Not at all" to 5 = "Very much".

The participants themselves defined their friendships as positive or negative by filling out the friendship scale twice. Specifically, they, first, completed it for the current quality of their friendship, and then, mentioned the lowest value in each item over which the friendship would be positive. Children whom the friendship was lower than the indicated as positive formed the group of negative friendship, while those whom friendship was equal or higher than the indicated one formed the group of positive friendship. Cronbach's alphas were 0.81 and 0.79 for the positive and negative friendship, respectively.

Attributions for friendship. Children's attributions for the perceived quality of their friendships with their best friend were estimated by responding to modified CDSII (Causal Dimension Scale II) (McAuley et al., 1992) which is a reliable and valid research instrument in examining attributions for intimate interpersonal relationships in Greek population (Stephanou, 2005; 2007; 2010). The children indicated the most important cause which, according to their opinion, influenced the quality of their friendship, how much this cause contributed to the perceived quality of the friendship and classified that cause along the attributional 
dimensions of locus of causality (internal/external causes to him/herself), stability (stable/unstable causes over time), personal controllability (controllable/uncontrollable causes by their own), external controllability (controllable/uncontrollable causes by others), friends' locus of causality (internal/external causes to their friend), friend's controllability (controllable/uncontrollable causes by their friends), self-friend interactive locus of causality (internal/external causes to interaction self-friend) and self-friend interactive controllability (controllable/uncontrollable causes by interaction self-friend). Each subscale consists of three items, ranging form the negative pole $1=$ "Not at all" stable to the positive pole $5=$ "Totally stable". Cronbach's alphas were: Locus of causality: 78 ; stability: 0.81 ; personal controllability: 0.73 ; external controllability: 76 ; friend's locus of causality: 79; friend's controllability: 80; self-friend interactive locus of causality: 74; and self-friend controllability: 72 .

Emotions for friendship. Children's emotions for their friendships with their best friend were assessed by mentioning the extent to which they experienced 12 emotions: happiness, pleasure, pride, encouragement, love, not angry-angry, cheerfulness, hope, calmness, not anxiety-anxiety, enthusiasm and excitement. The emotions had the form of adjectives with two opposite poles, with the positive pole having the high score of 5 and the negative one having the low score of 1 (e.g., happy 54321 unhappy). The consistency of the scale was based on previous research (Stephanou, 2004, 2005, 2007; Weiner, 1992, 2001).

Friendship expectations. Children's friendship expectations were examined via the scale of the perceived current quality of the friendship, changing the present verb tense into future (e.g., "How good will this friendship be in the future?" and "How much satisfied will you be with this friendship in the future?"). Cronbach's alpha was 0.82 .

Personal factors. A set of questions relevant to personal factors, such as age, grade and gender were the children's personal information scale.

\section{Procedure}

The children, first, wrote down the name of their best friend, and then, filled out the scales that referred to this specific friendship. The children individually completed the scales in front of the second author in quite classrooms in their schools. In order to ensure that any relationship between the attributional appraisal and emotions was not due to procedure used, the participants responded first to the emotions scale and then to attributions scale. Finally, they filled out the expectations scale. The children were assured of anonymity and confidentiality. To match the questionnaires that were responded by the same child, children were asked to choose a code name and use it on the questionnaires.

\section{Results}

\section{Attributions for the Perceived Positive and Negative Friendship}

Examination of the open-ended responses to attribution scale suggested that these could be categorized into the general categories presented in Table 1, confirming Hypothesis 1a. The reliability of this coding scheme was evaluated by asking two judges, who were familiar with attribution theory, to place each of the open-ended responses into one of these categories. There was a total agreement of $90 \%$ of the responses.

Analysis of frequencies of attributions revealed significant effects. More precisely, the perceived positive friendships were mainly attributed by the children to companionship and recreation (26\%), perceived help and support from friend (19.70\%), friends' good character (16.25\%) and lack of conflict with the friends (15.06), 
$x^{2}(6, N=183)=29.10, p<0.01$. In contrast, the perceived negative friendships were mainly attributed to non-exclusiveness (26.62\%), lack of companionship and recreation (17.95\%), friend's bad character (15.45\%) and conflict with the friends $(12.83 \%), x^{2}(6, N=40)=29.10, p<0.01$. In addition, the children, who perceived their friendships with their best friends as negative, compared to children, who perceived their friendships as positive, more often mentioned non-exclusiveness, $x^{2}(1, N=14)=26.28, p<0.01$.

Table 1

Frequency of Children's Attributions for Their Friendships (Positive/Negative)

\begin{tabular}{|c|c|c|c|c|}
\hline \multirow{2}{*}{ Attribution elements } & \multicolumn{2}{|c|}{ Positive friendships } & \multicolumn{2}{|c|}{ Negative friendships } \\
\hline & $f$ & Percentage (\%) & $f$ & Percentage $(\%)$ \\
\hline Companionship and recreation & 45 & 26.00 & 7 & 17.95 \\
\hline Help and support from friend & 34 & 19.70 & 4 & 10.30 \\
\hline Friend's character & 28 & 16.25 & 6 & 15.45 \\
\hline Conflict & 26 & 15.06 & 5 & 12.83 \\
\hline Solving conflict & 12 & 6.90 & 3 & 7.70 \\
\hline Intimacy and trust & 24 & 13.92 & 4 & 10.35 \\
\hline Exclusiveness & 4 & 2.35 & 10 & 25.62 \\
\hline
\end{tabular}

Note. The nature of attribution is positive and negative in positive and negative friendships group, respectively.

The findings regarding the attributional dimensions were in line with those of attribution elements. More accurately, the results from the repeated measures MANOVAs (using the Wilks's lambda estimate) with the eight attributional dimensions as within subjects factor and the perceived friendship with the best friend (positive/negative) as between-subjects factor revealed significant effect of the attributional dimensions, $F_{(7,217)}$ $=20.68, p<0.01, \eta^{2}=0.40$, significant effect of the perceived friendship, $F_{(1,223)}=44.50, p<0.01, \eta^{2}=0.22$ and significant multivariate effect $F_{(7,217)}=96.80, p<0.01, \eta^{2}=0.75$.

The results from subsequent repeated measures ANOVAs, examining differences between attributions within each group (positive/negative) of friendship, post hoc pairwise comparisons and the mean scores showed that the children made internal, personal controllable, external uncontrollable, friend's internal, and mainly stable, external uncontrollable and self-friend interactive internal attributions for the perceived positive friendships. In contrast, the children mainly attributed the negative friendships to friends' controllable, friends' internal, personally uncontrollable, external and unstable factors.

The results from discriminant analysis (see Table 2), with stepwise method, confirmed the univariate effects, and additionally, revealed that personal controllability, discriminating power $=0.70, d=0.94$, followed by stability, discriminating power $=0.51, d=0.72$ and self-friend interactive controllability, discriminating power $=0.49, d=0.67$ was the most powerful factor in discriminating the group of children who perceived their friendship as positive from the group of children who perceived their friendship as negative. Furthermore, the rest of the attributional dimensions had no significant contribution into separation the one from the other group of children.

Hypotheses $1 \mathrm{~b}$ and $1 \mathrm{c}$ were partly confirmed by the above findings.

\section{Emotions for the Perceived Positive and Negative Friendship}

The results from two repeated measures ANOVAs, one for each group of friendship (positive/negative), in which emotions were the within-subjects factor, revealed that the participants experienced various emotions and a variety of intensity of emotions for their perceived positive friendships, $F_{(11,174)}=13.70, p<0.01, \eta^{2}=$ 
0.44 , and for their perceived negative friendships, $F_{(11,29)}=9.60, p<0.01, \eta^{2}=0.77$.

Table 2

Descriptive Statistics and Results From Discriminant Analysis for Students' Attributional Dimensions for Their Perceived Positive and Negative Friendships

\begin{tabular}{|c|c|c|c|c|c|c|c|c|}
\hline \multirow[b]{2}{*}{ Attributional dimensions } & \multicolumn{2}{|c|}{$\begin{array}{l}\text { Positive } \\
\text { friendships }\end{array}$} & \multicolumn{2}{|c|}{$\begin{array}{l}\text { Negative } \\
\text { friendships }\end{array}$} & \multirow[b]{2}{*}{$\begin{array}{l}\text { Wilks' } \\
\text { Lambda }\end{array}$} & \multirow[b]{2}{*}{$\begin{array}{l}\text { Discriminating } \\
\text { power }\end{array}$} & \multirow[b]{2}{*}{$d$} & \multirow[b]{2}{*}{$F$} \\
\hline & Mean & $S D$ & Mean & $S D$ & & & & \\
\hline Locus of causality & 3.24 & 1.24 & 2.40 & 1.12 & 0.92 & -- & 0.53 & 17.55 \\
\hline Personal controllability & 2.89 & 1.46 & 1.22 & 0.76 & 0.80 & 0.70 & 0.94 & 53.60 \\
\hline Stability & 3.37 & 1.65 & 1.86 & 1.37 & 0.88 & 0.51 & 0.72 & 28.90 \\
\hline External controllability & 1.15 & 0.71 & 1.75 & 1.15 & 0.93 & -- & 0.57 & 16.52 \\
\hline Friend's locus of causality & 3.66 & 1.24 & 3.86 & 1.00 & 0.99 & -- & --- & --- \\
\hline Friend's personal controllability & 3.10 & 1.46 & 4.51 & 1.12 & 0.85 & -- & 0.78 & 38.25 \\
\hline $\begin{array}{l}\text { Self-friend interactive locus } \\
\text { of causality } \\
\text { Self-friend }\end{array}$ & 3.90 & 1.62 & 3.33 & 1.86 & 0.96 & -- & 0.45 & 5.19 \\
\hline interactive controllability & 2.81 & 1.91 & 1.26 & 0.90 & 0.89 & 0.49 & 0.57 & 28.52 \\
\hline
\end{tabular}

Notes. All $F_{(1,223)}=5.19, p<0.05$; All $F_{(1,223)}>5.19, p<0.01 ;---:$ Not significant at the significant level of 0.05 ; --: Attributional dimensions did not further differentiate the one group from the other group of children; $d$ : Cohen's $d$.

Post hoc pairwise comparisons and the scores (see Table 3) illustrated that the children experienced intense positive emotions, mainly enthusiasm, happiness, love, no anger and excitement, for their perceived positive friendships with their best friends, while they felt intense negative emotions, in particular shame, displeasure, unhappiness and no excitement, for their perceived negative friendships with their best friends.

Table 3

Descriptive Statistics and Findings From Discriminant Function Analysis for Children's Emotions for Their Perceived Positive and Negative Friendships

\begin{tabular}{|c|c|c|c|c|c|c|c|c|}
\hline \multirow[b]{2}{*}{ Emotions } & \multicolumn{2}{|c|}{$\begin{array}{l}\text { Positive } \\
\text { friendships }\end{array}$} & \multicolumn{2}{|c|}{$\begin{array}{l}\text { Negative } \\
\text { friendships }\end{array}$} & \multirow[b]{2}{*}{$\begin{array}{l}\text { Wilks' } \\
\text { Lambda }\end{array}$} & \multirow[b]{2}{*}{$\begin{array}{l}\text { Discriminating } \\
\text { power }\end{array}$} & \multirow[b]{2}{*}{ Cohen's $d$} & \multirow[b]{2}{*}{$F$} \\
\hline & Mean & $S D$ & Mean & $S D$ & & & & \\
\hline Happiness & 4.57 & 0.75 & 2.08 & 0.73 & 0.35 & 0.81 & 2.57 & 411.65 \\
\hline Pleasure & 4.39 & 0.76 & 2.00 & 0.23 & 0.32 & 0.86 & 2.64 & 462.25 \\
\hline Pride & 4.39 & 0.76 & 2.00 & 0.23 & 0.39 & 0.73 & 2.31 & 336.50 \\
\hline Love & 4.16 & 0.80 & 1.85 & 0.58 & 0.36 & -- & 2.44 & 386.35 \\
\hline Encouragement & 4.59 & 0.68 & 2.50 & 0.56 & 0.79 & 0.30 & 0.96 & 56.00 \\
\hline No anger-angry & 4.23 & 0.92 & 3.03 & 1.14 & 0.40 & -- & 2.19 & 332.84 \\
\hline Cheerfulness & 4.56 & 0.68 & 2.60 & 0.71 & 0.38 & -- & 2.28 & 355.62 \\
\hline Excitement & 4.49 & 0.72 & 2.42 & 0.59 & 0.36 & 0.79 & 2.44 & 368.06 \\
\hline Hope & 4.46 & 0.75 & 2.17 & 0.55 & 0.80 & 0.30 & 0.94 & 52.53 \\
\hline Calmness & 4.21 & 0.94 & 3.03 & 1.14 & 0.70 & -- & 1.45 & 82.25 \\
\hline No anxiety-anxiety & 4.05 & 0.88 & 2.80 & 0.65 & 0.74 & 0.45 & 1.11 & 77.32 \\
\hline Enthusiasm & 4.06 & 0.87 & 2.85 & 0.70 & 0.38 & -- & 2.37 & 352.10 \\
\hline
\end{tabular}

Notes. All $F_{(1,223)}$-values, $p<0.01$; The nature of the emotions is positive and negative in the positive and negative friendships group, respectively; --: Emotions did not further differentiate the one group from the other group of children. 
The results from subsequent discriminant function analysis (see Table 3) with stepwise method confirmed that the children, who estimated their friendship as positive, as compared to children, who estimated their friendship as negative, felt better, and, in addition, showed that the emotion of pleasure, discriminating power $=$ $0.86, d=2.64$, followed by the emotions of happiness, discriminating power $=0.81, d=2.57$, excitement, discriminating power $=0.79, d=2.44$, and pride, discriminating power $=0.73, d=2.31$ was the most powerful factor in discriminating the two groups of children. However, five emotions were found not to further differentiate the one group from the other group of children.

The above findings partly confirmed Hypotheses 2 .

\section{Effects of Intuitive and Attributional Appraisals of Friendships on Emotions}

The results from correlations' coefficients and a series of regression analyses, with intuitive appraisal and attributional appraisal of the friendship as predictive variables and each of the emotions as predicted variable, within each group of children (perceived positive/negative friendships) (see Table 4) showed that: (1) The more positive friendship a child had, the more intense the positive emotions, mainly love, excitement, enthusiasm, cheerfulness and happiness; (2) The more negative friendship a child had, the more intense the negative emotions, mainly displeasure and not excitement; (3) By attributing the positive friendships to internal factors, the children maximized the emotion of pride, while by attributing it to stable factors, they felt the intense positive emotions of pleasure, encouragement and hope; (4) By attributing the negative friendships to personal uncontrollable causes and, in particular to unstable factors, the participants minimized the intensity of both hopelessness and discouragement and discouragement, hopelessness, anger and sadness, respectively; (5) Stability, compared to the other attributional dimensions, proved the most powerful predictor of most of the emotions in the positive friendships group, and, particularly, in the negative friendships group; (6) Attributional appraisal, compared to intuitive appraisal of friendship, was a better predictor of the emotions of encouragement and hope in the positive friendships group, while it was a more powerful factor of all of the attribution-dependent emotions in the negative friendships group; (7) In contrast, the intuitive appraisal, in comparison to attributional appraisal, explained a greater amount of the variance of all of the outcome-dependent emotions in the positive friendships group, and the emotions of not excitement and displeasure in the negative friendships group, respectively; and (8) Intuitive appraisal and attributional appraisal, in combination, accounted for significant variance of the emotions for the perceived positive friendships, $R^{2}$ ranged from 0.05 (pleasure) to 0.60 (enthusiasm), and for the negative friendships, $R^{2}$ ranged from 0.16 (shame) to 0.56 (hopelessness and discouragement).

The above findings are partly in agreement with Hypotheses $3 a$ and $3 b$.

\section{Effects of Attributional and Intuitive Appraisals on the Impact of Emotions on Friendship Expectations}

The results from correlations coefficients analyses and two hierarchical regression analyses ${ }^{1}$, in each group of children, with friendship expectations as predicted variable and emotions entering into first step and attributions and intuitive appraisal, together, entering into second step of the analysis, revealed the following.

In the positive friendships group, the children, who had high friendship expectations, highly estimated the current quality of their friendships, $r=0.25$, experienced intense positive emotions (except for not angry, cheerfulness and happiness), particularly encouragement, $r=0.57$, and hope, $r=0.56$, and made more stable attributions, $r=0.41$. In addition, (1) the two sets of predictors, together, had a significant and positive effect

\footnotetext{
${ }^{1}$ Only the variables that were significantly related to each other were included in the analysis.
} 
on friendship expectations, $R^{2}=0.51, F_{(11,173)}=16.20, p<0.01$; (2) emotions accounted for a significant variability in friendship expectations, $R^{2}=0.37, F_{(9,175)}=11.72, p<0.01$; (3) attributional and intuitive appraisals, as a group, enhanced the impact of the emotions on friendship expectations, $R^{2} c h=0.13, F c h_{(2,173)}=$ 22.95, $p<0.01$; and (4) pleasure, $b=0.60, t=2.70, p<0.01$, stability, $b=0.31, t=5.23, p<0.01$, and intuitive appraisal, $b=0.88, t=4.40, p<0.01$, contributed into friendship expectations.

Table 4

Results From Multiple Regression Analyses for the Effects of Intuitive and Attributional Appraisals of Friendships on the Emotions for the Perceived Positive and Negative Friendships

\begin{tabular}{|c|c|c|c|c|c|}
\hline Emotions & Predictors & Beta & $t$ & $F(d f)$ & $R^{2}$ \\
\hline \multicolumn{6}{|l|}{ Positive friendships } \\
\hline Happiness & Intuitive appraisal & 0.68 & 12.53 & $157.10(1,183)$ & 0.46 \\
\hline \multirow[t]{2}{*}{ Pleasure } & Stability & 0.19 & 2.51 & \multirow{2}{*}{$6.28(2,182)$} & \multirow{2}{*}{0.05} \\
\hline & Self-friend controllability & 0.11 & -- & & \\
\hline \multirow[t]{4}{*}{ Pride } & Locus of causality & 0.29 & 3.36 & \multirow{4}{*}{$33.79(4,180)$} & \multirow{4}{*}{0.43} \\
\hline & Friend's locus of causality & -0.03 & -- & & \\
\hline & Personal controllability & -0.00 & -- & & \\
\hline & Intuitive appraisal & 0.60 & 10.35 & & \\
\hline Love & Intuitive appraisal & 0.69 & 12.72 & $161.72(1,183)$ & 0.47 \\
\hline Encouragement & Stability & 0.31 & 4.44 & $19.69(1,183)$ & 0.08 \\
\hline No anger & Intuitive appraisal & 0.65 & 11.69 & $136.64(1,183)$ & 0.42 \\
\hline \multirow[t]{2}{*}{ Cheerfulness } & Stability & 0.05 & -- & \multirow{2}{*}{$88.45(4,180)$} & \multirow{2}{*}{$0.4 \mathrm{C}$} \\
\hline & Intuitive appraisal & 0.69 & 12.72 & & \\
\hline \multirow[t]{3}{*}{ Excitement } & Stability & 0.04 & -- & \multirow{3}{*}{$86.43(4,180)$} & \multirow{3}{*}{0.59} \\
\hline & Self-friend controllability & 0.05 & -- & & \\
\hline & Intuitive appraisal & 0.77 & 15.54 & & \\
\hline Hope & Stability & 0.30 & 4.23 & $17.88(1,183)$ & 0.08 \\
\hline Calmness & Intuitive appraisal & 0.34 & 4.94 & $24.42(1,183)$ & 0.11 \\
\hline Not anxiety & Intuitive appraisal & 0.33 & 4.75 & $22.54(1,183)$ & 0.11 \\
\hline \multirow[t]{4}{*}{ Enthusiasm } & Friend's locus of causality & -0.60 & -- & \multirow{4}{*}{$66.55(4,180)$} & \multirow{4}{*}{0.60} \\
\hline & Stability & 0.02 & -- & & \\
\hline & Self-friend controllability & 0.04 & -- & & \\
\hline & Intuitive appraisal & 0.76 & 15.47 & & \\
\hline \multicolumn{6}{|c|}{ Negative friendships } \\
\hline Unhappiness & Stability & -0.44 & 2.98 & $8.88(1,38)$ & 0.17 \\
\hline Displeasure & Intuitive appraisal & 0.72 & 6.32 & $40.00(1,38)$ & 0.50 \\
\hline Shame & Stability & -0.43 & -2.91 & $8.49(1,38)$ & 0.16 \\
\hline Hate & Stability & -0.51 & -3.69 & $13.62(1,38)$ & 0.24 \\
\hline \multirow[t]{2}{*}{ Discouragement } & Stability & -0.71 & -6.51 & \multirow{2}{*}{$25.81(2,37)$} & \multirow{2}{*}{0.56} \\
\hline & Personal controllability & -0.46 & -4.23 & & \\
\hline Anger & Stability & -0.65 & -5.30 & $28.10(1,38)$ & 0.41 \\
\hline Sadness & Stability & -0.50 & -3.59 & $12.90(1,38)$ & 0.23 \\
\hline \multirow[t]{2}{*}{ Not excitement } & External controllability & 0.28 & -- & \multirow{2}{*}{$4.58(2,37)$} & \multirow{2}{*}{0.20} \\
\hline & Intuitive appraisal & 0.32 & 2.14 & & \\
\hline \multirow[t]{2}{*}{ Hopelessness } & Stability & -0.72 & -6.86 & \multirow{2}{*}{$25.81(2,37)$} & \multirow{2}{*}{0.56} \\
\hline & Personal controllability & -0.46 & -4.39 & & \\
\hline Nervousness & Stability & -0.56 & -4.21 & $17.73(1,38)$ & 0.30 \\
\hline Anxiety & Stability & -0.57 & -4.98 & $18.17(1,38)$ & 0.31 \\
\hline Not enthusiasm & Stability & -0.26 & -- & $412(2 \quad 37)$ & 018 \\
\hline & Intuitive appraisal & 0.28 & -- & $4.12(2,31)$ & 0.18 \\
\hline
\end{tabular}

Notes. Only the variables that were significantly related to each other were included in the analysis; All $F$-values, $p<0.01 ;--$ : Not significant contribution in the generation of emotion; $t>2.51, p<0.01, t \leq 2.51, p<0.05$. 
In the negative friendships group, the children, who had higher friendship expectations, as compared to children, who had lower friendship expectations, perceived the current quality of their friendships as less negative, $r=0.50$, felt less intense negative emotions, mainly, discouragement, $r=0.79$, hopelessness, $r=0.75$, hate, $r=0.61$ and angry, $r=0.60$, and made more unstable attributions, $r=0.46$. Additionally, (1) emotions and appraisals of the friendship, as a group, had a significant and positive impact on friendship expectations, $R^{2}$ $=0.75, F_{(14,25)}=7.30, p<0.01$; (2) emotions explained a significant portion of the variability in friendship expectations, $R^{2}=0.67, F_{(12,27)}=6.70, p<0.01$; (3) attributional appraisal and intuitive appraisal, in combination, influenced the effect of the emotions on friendship expectations, $R^{2} c h=0.073, F c h_{(2,25)}=4.22, p$ $<0.05$; and (4) discouragement, $b=0.40, t=2.70, p<0.01$, and intuitive appraisal, $b=0.39, t=2.89, p<0.01$, had unique effect on the formulation of friendship expectations.

Hypotheses $4 \mathrm{a}$ and $4 \mathrm{~b}$ were partly confirmed by the above findings.

\section{Discussion}

This study mainly aimed to examine possible differences between the children who perceive their friendship with their best friend either as positive or negative with respect to attributions and emotions, and the role of appraisals of the friendship in the generation of the emotions and the impact of the emotions on friendship expectations.

The findings regarding the attributional pattern of the friendship were in the main as expected. Specifically, the children attributed their friendships with their best friends to various factors, reflecting the high importance of such relationships in their life (Argyle, 2001; Berndt, 2004; Bukowski, 2001; Holder \& Coleman, 2009; Stephanou, 2010). Also, the attributional pattern within and between positive and negative friendships group underlines the desirable good friendship (Gifford-Smith \& Brownell, 2003; Harvey et al., 2005; Hoglund et al., 2008; Weiner, 2002, 2005). Specifically, by attributing the positive friendships to stable and personal properties, along with friend-related factors, self-friends interactive and internal causes, the participants enhanced themselves, multiplied the chances of good relationship in the future, and, simultaneously, indicated the crucial role of the friend in forming a satisfactory friendship (Fiedler et al., 1995; Fincham, 2003; Rusbult, Arriaga, \& Agnew, 2003; Weiner, 2001). By attributing the negative friendships to unstable, external, personal uncontrollable and friends' internal and controllable bad factors, the children protected themselves (Stephanou, 2005, 2007; Weiner, 2001). However, it should be mentioned that considering the friend as responsible for the negative friendship does not facilitate future positive relationship (Karney et al., 2003; Mason, 2001; Weiner, 1995, 2001). Similarly, considering the friends' negative properties as a major contributor into negative friendship minimizes the chances of positive friendship in the future (Fletcher, 2002; Fincham et al., 1998; Planalp \& Rivers, 1996).

The age of the participants might be another explanation of the above findings, since children, at this age, in order to enhance the quality of their close relationships, focus on solving short-term difficulties which are mainly related to their partners (Hoglund et al., 2008; Pillow et al., 2008). The age also influenced the attributional elements. More precisely, in the positive friendships group, the findings, confirming previous researches (Asher \& Rose, 1997; Berndt, 2004; Brendgen, Vitaro, Turgeon, \& Poulin, 2002; Gifford-Smith \& Brownell, 2003), underline the significant role of companionship, recreation and support in middle childhood friendship (Bukowski, Hoza, \& Boivin, 1993; Hartup, French, Laursen, Johnston, \& Ogawa, 1993). Similarly, in the negative friendships group, the results, being partly in inconsistency with other researches (Asher \& Rose, 1997; Brendgen et al., 2002; Parker \& Asher, 1993; Rubin, Bukowski, \& Parker, 1998), emphasize the friend's 
non-exclusiveness. By doing this, the children, on the one hand, protected themselves, and, on the other hand, protected their friendships and showed their need to be accepted by their friends (Branje, Frijns, Finkenauer, Engels, \& Meeus, 2007).

In sum, the findings with respect to emotions were mainly in accordance to our expectations and literature. Perhaps, it was very important for the children to have positive friendships, since they reacted affectively in high intense (Forgas, 2002; Forgas \& Smith, 2005; Frijda, 1993, 2009; Hyson, 2000). Also, the children, being at the specific age, might have expected positive friendships and confirmation of their produced intense positive emotions (Bless, 2003; Rockhill, Fan, Katon, McCauley, Crick, \& Pleck, 2007; Trope \& Gaunt, 2005), while, the friends' unexpected bad behavior contributed into intense negative emotions. This argument is related to the Berscheid's (1983) emotion-in-relationships model suggesting the greater the interruption when one partner does something unexpected, or fails to do something expected, the higher the intensity of the experienced emotions. Additionally, it seems that the children's negative friendships with their best friends were against their desires, since under such conditions persons experience intense negative emotions (Berscheid \& Ammazalorso, 2003; Carver \& Scheier, 2000; Forgas, 2002; Frijda, 2007, 2009; Parrott, 2003). The fact that the group of children with the positive friendships was discriminated from the group of children with the negative friendships predominately by the outcome-dependent affects (happiness and pleasure), followed by the expectancy-related affects (excitement), and self-esteem related affects (pride) is also in line with these speculations and Weiner's $(2002 ; 2005)$ theory.

Interestingly, it also seems that the children considered the development of their friendship, since, based on Seligman's (2002) view of classification of emotions, they experienced emotions which are related to the past (e.g., pride/shame), the present (e.g., pleasure/displeasure) and the future (e.g., hope/hopelessness, enthusiasm/non-enthusiasm).

It should be mentioned, however, that the experience of some certain negative emotions does not facilitate future good friendship. For example, previous research evidence suggests that anger is positively related to attribute malicious intentions to other, anxiety enhances the belief that threating events are about to occur, and sadness shapes malicious attributions for conflicts in close relationships (Fitness et al., 2005; Forgas, 1994, 1995; Planalp \& Fitness, 1999).

Children also experienced discrete emotions by cognitively appraised their friendships along the attributional dimensions. This finding is in agreement with other researches (Bradbury \& Fincham, 1987; Fitness \& Fletcher, 1993; Planalp \& Fitness, 1999; Stephanou, 2007, 2011) in intimate relationships. The fact that attributions were more powerful contributor in the generation of the emotions in negative than positive friendships is consistent with the notion that individuals search for explanations of their negative than positive experiences (Siemer, Mauss, \& Gross, 2007; Weiner, 2002). Stability, compared to the rest of the attributional dimensions, proved the most significant predictor of most of the emotions, contrarily to the notion that each attributional dimension is related to specific kind of emotions (Weiner, 2002; 2006). However, as expected, locus of causality influenced the emotions of pride, while personal controllability had a unique effect on the emotion of hopelessness, enhancing, thus, self-esteem.

Intuitive appraisal, compared to attributional appraisal, of the friendship was a better predictor of most of the emotions for the positive friendships, proposing the high importance of the friendships itself in children's emotional experience (Gifford-Smith \& Brownell, 2003). In the negative friendship, the pattern was the other way around, suggesting the children's effort to explain negative friendships (Fincham, 2003; Weiner, 2001). 
The results from the present study also, confirming in the main our hypotheses, showed that cognitive appraisals and emotions for the friendship had a unique and complimentarily effect on friendship expectations. Specifically, the three sets of concepts, in combination, proved a more powerful predictor of the expectations in negative than positive friendship group, supporting further the earlier findings (Fitness et al., 2005; Forgas \& Smith, 2005; Greitemeyer \& Weiner, 2003; Harvey et al., 2005; Stephanou, 2007; Weiner, 2002, 2005). Also, in agreement with Weiner's (2002) model, the future (discouragement) and desirable friendship (pleasure)-related emotions contributed in friendship expectations, in the negative and positive friendship, respectively. Stability, as expected, was a significant factor of the formation of friendship expectation in the positive friendship group, while, unexpectedly, it had no effect on negative friendship group, reflecting, probably, children's beliefs that the negative friendship can become positive, only if they can control situation and interact effectively with their friends. Also, the intuitive appraisal of the current quality of the friendship was the most powerful formulator of friendship expectation, particularly in the positive friendships group, underling its significant role in children's life.

\section{Implications of the Findings to Children Life and Future Research}

Good friendship proved to be important for the children. Children should be helped develop the capacity to make and maintain stable and satisfying friendships. This capacity is acquired through personal, historical and environmental factors (Blas, 2007; Buss, 2000; Carr, 2005). Children should be encouraged by school, the family and the community to meet peers, at least some of whom have similar skills, attributes and values. Children should be also supported to develop personal factors, such as an optimistic thinking style, hopeful thinking and high self-esteem (Carver \& Scheier, 2005; Peterson \& Steen, 2005; Snyder, 2000).

The present findings also revealed that the participants were involved in their friendships cognitively and emotionally, and these processes had a significant effect on friendship expectations. Attributional retraining (Seligman, 2002) helps children to change maladaptive attributional pattern of friendships, and understanding the nature and function of emotions within positive/negative friendship is essential. Yet, emotional expression influences partners' behaviour (Clark, Pataki, \& Carver, 1996), and children are needed to be aware of it.

Overall, the findings from this study indicate the importance of examining children friendship along attributing causes, experiencing emotions and forming expectations. Research is needed to examine the role of children's socio-cognitive factors, such as self-efficacy and significant others' support, and their past experience and beliefs about the ideal friendship on the observed associations and the friendship development. Research also needs to investigate the consequences of the emotional and cognitive pattern in relationship judgments and behaviours.

\section{References}

Argyle, M. (2001). Social relationships. In M. Hewstone, W. Stroebe, J. P. Codol, \& G. M. Stepheson (Eds.), Introduction to social psychology. Oxford: Blackwell.

Asher, S. R., \& Rose, A. J. (1997). Promoting children's social-emotional adjustment with peers. In P. Salovey, \& D. Sluyter (Eds.), Emotional development and emotional intelligence: Educational implications. USA: BasicBooks.

Aspinwall, L. G., \& Staudinger, U. M. (2003). A psychology of human strengths: Some central issues of an emerging field. In L. G. Aspinwall, \& U. M. Staudinger (Eds.), A psychology of human strengths: Fundamental questions and future directions for a positive psychology (pp. 9-22). San Francisco, C. A.: Berrett-Koehler Publishers Inc.. 
Baucom, D. H., Epstein, N. B., \& Stanton, S. (2006). The treatment of relationship distress: Theoretical perspectives and empirical findings. In A. L. Vangelistic, \& D. Perlman (Eds.), The Cambridge handbook of personal relationships (pp. 750-773). N.Y: Cambridge University Press.

Berndsen, M., \& Manstead, A. S. R. (2007). On the relationship between responsibility and guilt: Antecedent appraisal or elaborated appraisal? European Journal of Social Psychology, 37, 774-792.

Berndt, T. J. (2004). Children's friendships: Shifts over a half century in perspectives on their development and effects. Merrill Palmer Quarterly, 50(3), 206-223.

Berscheid, E. (1983). Emotion. In H. H. Kelley, E. Berscheid, A. Christensen, J. H. Harvey, T. L. Huston, G. Levinger, E. Mclintock, I. A. Reptan, \& D. R. Peterson (Eds.), Close relationships (pp. 110-168). New York: Freemen.

Berscheid, E., \& Ammazzalorso, H. (2003). Emotional experience in close relationships. In G. J. O. Fletcher, \& M. S. Clark (Eds.), Handbook of social psychology: Interpersonal processes (pp. 308-330). Oxford: Blackwell.

Bigelow, B. J. (1997). Children's friendship expectations: A cognitive developmental study. Child Development, 48, $246-253$.

Blascovich, J., \& Mandes, W. B. (2000). Challenge and threat appraisals: The role of affective cues. In J. P. Forgas (Ed.), Feeling and thinking: The role of affect in social cognition (pp. 131-152). New York: Cambridge University Press.

Blas, L. D. (2007). A circumplex model of interpersonal attributes in middle childhood. Journal of Personality, 75(4), 863-897.

Bless, H. (2003). The consequences of mood on the processing of social information. In A. Tesser, \& N. Schwarz (Eds.), Handbook of social psychology: Intraindividual processes (pp. 391-412). Oxford: Blackwell.

Bowker, J. C., Rubin, K. H., Burgess, K. B., Booth-LaForce, C., \& Rose-Krasnor, L. (2006). Behavioral characteristics associated with stable and fluid best friendship patterns in middle childhood. Merril-Palmer Quarterly, 52(4), 671-693.

Bradbury, T. N., \& Fincham, F. D. (1987). Affect and cognition in close relationships: Towards an integrative model. Cognition and Emotion, 1, 59-87.

Branje, S. J. T., Frijns, T., Finkenauer, C., Engels, R., \& Meeus, W. (2007). You are my best friend: Commitment and stability in adolescents' same-sex friendships. Personal Relationships, 14, 587-603.

Brendgen, M., Vitaro, F., Turgeon, L., \& Poulin, F. (2002). Assessing aggressive and depressed children's social relations with classmates and friends: A matter of positive perspective. Journal of Abnormal Child Psychology, 30(6), 609-624.

Bukowski, W. M. (2001). Friendship and the worlds of childhood. In D. W. Nagle, \& C. A. Erdley (Eds.), The role of friendship in psychological adjustment: New directions for child and adolescent development (Vol. 91, pp. 93-106). San Francisco: Jossey-Bass.

Bukowski, W. M., Hoza, B., \& Boivin, M. (1993). Popularity, friendship, and emotional adjustment during early adolescence. New Directions for Child Development, 60, 23-37.

Buss, D. (2000). The evolution of happiness. American Psychologist, 55, 15-23.

Buss, D. (2005). The handbook of evolutionary psychology. N. J.: Wiley.

Carr, A. (2005). Positive psychology. London: Routledge.

Carver, C. S., \& Scheier, M. F. (2000). Scaling back goals and readibration of the affect system are processes in normal adaptive self-regulation: Understanding "response shift" phenomena. Social Science and Medicine, 50, 1715-1722.

Carver, C. S., \& Scheier, M. F. (2005). Optimism. In C. R. Snyder, \& S. J. Lopez (Eds.), Handbook of positive psychology (pp. 231-256). Oxford: University Press.

Clark, M. S., Fitness, J., \& Brissette, I. (2003). Understanding people's perceptions of relationships is crucial to understanding their emotional lives. In G. J. O. Fletcher, \& M. S. Clark (Eds.), Handbook of social psychology: Interpersonal processes (pp. 253-278). Oxford: Blackwell.

Clark, M. S., Pataki, S., \& Carver, V. (1996). Some thoughts and feelings on self-presentation of emotions in relationships. In G. J. O. Fletcher, \& J. Fitness (Eds.), Knowledge structures in close relationships: A social psychological approach (pp. 247-274). New Jersey: Lawrence Erlbaum.

Clore, G. L., \& Ortony, A. (2010). Appraisal theories: How cognition shapes affects into emotion. In M. Lewins, J. M. Haviland-Jones, \& L. F. Barret (Eds.), Handbook of emotions (pp. 628-644). Yew York: Guilford.

Cohen, J. (1992). A power primer. Psychological Bulletin, 112, 155-159.

Cole, M., \& Cole, S. R. (2001). The development of children. N. Y.: Freeman.

Collins, N. L., Ford, M. B., Guichard, A. C., \& Allard, L. M. (2006). Working models of attachment and attribution processes in intimate relationships. Personality and Social Psychology Bulletin, 32, 201-219.

Colonnesi, C., Engelhard, I. M., Bogels, S. M. (2009). Development in children's attribution of embarrassment and the relationship with theory of mind and shyness. Cognition and Emotion, 22, 1-11. 
Diener, E. (1984). Subjective well-being. Psychological Bulletin, 96, 542-575.

Diener, E. (2000). Subjective well-being. The science of happiness and a proposal for national index. American Psychologist, 55(1), 34-43.

Diener, E., \& Seligman, M. (2002). Very happy people. Psychological Science, 13, 81-84.

Diener, E., Lucas, R. E., \& Oishi, S. (2005). Subjective well-being: The science of happiness and life satisfaction. In C. R. Snyder, \& S. J. Lopez (Eds.), Handbook of positive psychology (pp. 63-73). Oxford: University Press.

Dryfoos, J. G. (1998). Safe passages: Making it through adolescence in a risky society. Oxford: University Press.

Eccles, J. S., \& Wigfield, A. (2002). Motivational beliefs, values and goals. Annual Review of Psychology, 53, 109-132.

Efklides, A. (2001). Metacognitive experiences in problem solving: Metacognition, cognition and self regulation. In A. Efklides, J. Kuhl, \& R. M. Sorrrentino (Eds.), Trends and prospects in motivation research (pp. 297-323). Dordrecht, The Netherands: Kluwer.

Erber, R., \& Gilmour, R. (1995). Theoretical frameworks for personal relationships. Hillsdale, N. J.: Lawrence Erlbaum.

Erdley, C. A., Nangle, D. W., Newman, J. E., \& Carpenter, E. M. (2001). Children's friendship experiences and psychological adjustment: Theory and research. New Directions for Child and Adolescent Development, 91, 5-23.

Fehr, B., \& Harasymchuk, C. (2005). The experience of emotion in close relationships: Toward an integration of the emotion-in-relationships and interpersonal script models. Personal Relationships, 12, 181-196.

Fiedler, K., Semin, G. R., Finkenauer, D., \& Berkel, I. (1995). Actor-observer bias in close relationships. Personality and Social Psychology Bulletin, 21, 525-538.

Fincham, F. D. (2003). Attributions in close relationships: From balkanization to integration. In G. J. O. Fletcher, \& M. S. Clark (Eds.), Handbook of social psychology: Interpersonal processes (pp. 3-31). Oxford: Blackwell.

Fincham, F. D., Beach, S. R., Arias, I., \& Brody, G. (1998). Children's attributions in the family: The children's relationship attribution measure. Journal of Family Psychology, 12, 481-493.

Fitness, J., \& Fletcher, G. J. O. (1993). Love, hate, anger and jealousy in close relationships: A cognitive appraisal and prototype analysis. Journal of Personality and Social Psychology, 65, 942-958.

Fitness, J., Fletcher, G. J. O., \& Overall, N. (2005). Interpersonal attraction and intimate relationships. In M. A. Hogg, \& J. Cooper (Eds.), Handbook of social psychology (pp. 258-278). London: Sage.

Fletcher, G. J. O. (2002). The new science of intimate relationships. Oxford: Basil Blackwell.

Fletcher, G. J. O., \& Clark, M. S. (2003). Introduction. In G. J. O. Fletcher, \& M. S. Clark (Eds.), Handbook of social psychology: Interpersonal processes. Oxford: Blackwell.

Fletcher, G. J. O., \& Thomas, G. (1996). Close relationship lay theories: Their structure and function. In G. J. O. Fletcher, \& J. Fitness (Eds.), Knowledge structures in close relationships: A social psychological approach. New Jersey: Lawrence Erlbaum.

Fletcher, G. J. O., \& Thomas, G. (2000). Behavior and on-line cognition in marital interaction. Personal Relationships, 7 , 111-130.

Fletcher, G. J. O., Fitness, J., \& Blampied, N. M. (1990). The link between attributions and happiness in close relationships: The role of depression and explanatory style. Journal of Social and Clinical Psychology, 9, 243-255.

Forgas, J. P. (1994). Sad and guilty? Affective influences on the explanation of conflict episodes. Journal of Personality and Social Psychology, 66, 56-68.

Forgas, J. P. (1995). Mood and judgement: The affect infusion model (AIM). Psychological Bulletin, 117(1), 39-66.

Forgas, J. P. (2002). Feeling and doing: Affective influences on interpersonal behavior. Psychological Inquiry, 13, 1-28.

Forgas, J. P., \& Smith, C. A. (2005). Affect and emotion. In M. A. Hogg, \& J. Cooper (Eds.), Handbook of social psychology (pp. 161-189). London: Sage.

Frijda, N. H. (Ed.). (1993). Appraisal and beyond: Special issue of cognition and emotion. Hillsdale, N. J.: Erlbaum.

Frijda, N. H. (2007). The laws of emotion. Mahwah: Erlbaum.

Frijda, N. H. (2009). Emotions, individual differences, and time course: Reflections. Cognition and Emotion, 23, $1444-1461$.

Galanaki, E. (2003). Themes about developmental psychology. Athens: Atrapos. (in Greek)

Gifford-Smith, M. E., \& Brownell, C. A. (2003). Childhood peer relationship: Social acceptance, friendships, and peer networks. Journal of School Psychology, 41, 235-284.

Gilbert, D. T., \& Malone, P. S. (1995). The correspondence bias: The what, when, how and why of unwarranted dispositional inference. Psychological Bulletin, 111, 21-38.

Graham, S., \& Hoehn, S. (1995). Children's understanding of aggression and withdrawal as social stigmas: An attributional analysis. Child Development, 66, 1143-1161. 
Greitemeyer, T., \& Weiner, B. (2003). Asymmetrical attributions for approach versus avoidance behavior. Personality and Social Psychology Bulletin, 29, 1371-1382.

Hartup, W. W. (1996). The company they keep: Friendships and their developmental significance. Child Development, 67, 1-13.

Hartup W. W., French, D. C., Laursen, B., Johnston, M. K., \& Ogawa, J. R. (1993). Conflict and friendship relations in middle childhood: Behavior in a closed-field situation. Child Development, 64, 445-454.

Harvey, J. H. (1987). Attributions in close relationships: Research and theoretical development. Journal of Social and Clinical Psychology, 5, 8-20.

Harvey, J. H., \& Omarzu, J. (1999). Minding the close relationship. Personality and Social Psychology Review, 1, $223-239$.

Harvey, J., Pauwels, B., \& Zickmund, S. (2005). Relationship connections: The role of minding in the enhancement of closeness. In C. R. Snyder, \& S. Lopez (Eds.), Handbook of positive psychology (pp. 423-434). Oxford: University Press.

Hewstone, M., \& Antaki, M. (2001). Attribution theory and social explanations. In M. Hewstone, W. Stroebe, J. P. Codol, \& G. M. Stepheson (Eds.), Introduction to social psychology (pp. 111-141). Oxford: Basil Blackwell.

Hoglund, W. L. G., Lalonde, C. E., \& Leadbeater, B. J. (2008). Social-cognitive competence, peer rejection and neglect, and behavioral and emotional problems in middle childhood. Social Development, 17(3), 528-553.

Holder, M. D., \& Coleman, B. (2009). The contribution of social relationships to children's happiness. Journal of Happiness Studies, 10, 329-349.

Hyson, M. (2000). The emotional development of young children: Building an emotion-centered curriculum. New York: Teachers College Press-Columbia University.

Jenkins, J. M., \& Ball, S. (2000). Distinguishing between negative emotions: Children's understanding of the social-regulatory aspects of emotions. Cognition and Emotion, 14(2), 261-282.

Juvonen, I., \& Weiner, B. (1993). An attributional analysis of students interactions: The social consequences of perceived responsibility. Educational Psychology Review, 5, 325-345.

Karney, B. R., McNulty, J. K., \& Bradbury, T. N. (2003). Cognition and the development of close relationships. In G. J. O. Fletcher, \& M. S. Clark (Eds.), Handbook of social psychology: Interpersonal processes (pp. 32-59). Oxford: Blackwell.

Keltner, D., Ellsworth, P. C., \& Edwards, K. (1993). Beyond simple pessimism: Effects of sadness and anger on social judgment. Journal of Personality and Social Psychology, 64, 740-752.

Leary, M. R. (2000). Affect, cognition and the social emotions. In J. P. Forgas (Ed.), Feeling and thinking: The role of affect in social cognition (pp. 331-356). Cambridge: University Press.

Lewis, H. A., \& Kliewer, W. (1996). Hope, coping, and adjustment among children with sickle cell disease. Tests of mediator and moderator models. Journal of Pediatric Psychology, 21, 25-41.

McAuley, E., Duncan, T. E., \& Russell, D. W. (1992). Measuring causal attributions: The revised causal dimension scale (CDSII). Personality and Social Psychology Bulletin, 18, 566-573.

Myers, D. (2000). The funds, friends and faith of happy people. American Psychologist, 55, 56-67.

Nolen-Hoeksema, S., \& Davis, C. G. (2005). Positive responses to loss: Perceiving benefits and growth. In C. R. Snyder, \& S. J. Lopez (Eds.), Handbook of positive psychology (pp. 598-607). Oxford: University Press.

Oatley, K., \& Jenkins, J. (1998). Understanding emotions. Cambridge: Blackwell.

Ortony, A., Clore, G. L., \& Collins, A. (1988). The cognitive structure of emotions. Cambridge: University Press.

Overwalle, F., Heylighen, F., Casaer, S., \& Daniels, M. (1992). Pre-attributional and attributional determinants of emotions and expectations. European Journal of Social Psychology, 22, 313-329.

Parker, J. G., \& Asher, S. R. (1993). Friends and friendship in middle childhood: Links with peer group acceptance and feeling of loneliness and social dissatisfaction. Developmental Psychology, 29, 611-621.

Parrott, W. G. (2003). The nature of emotions. In A. Tesser, \& N. Schwarz (Eds.), Handbook of social psychology: Intraindividual processes (pp. 375-390). Oxford: Blackwell.

Peterson, C., \& Steen, T. A. (2005). Optimistic explanatory style. In C. R. Snyder, \& S. J. Lopez (Eds.), Handbook of positive psychology (pp. 244-256). Oxford: University Press.

Pillow, B. H., Lovett, S. B., \& Hill, V. (2008). Children's, adolescents', and adults' reference to goals to explain interpersonal actions. Infant and Child Development, 17, 471-489.

Planalp, S., \& Fitness, J. (1999). Thinking/feeling about personal and social relationships. Journal of Social and Personal Relationships, 16, 731-750.

Planalp, S., \& Rivers, M. (1996). Changes in knowledge of personal relationships. In G. J. O. Fletcher, \& J. Fitness (Eds.), Knowledge structures in close relationships: A social psychological approach. N. J.: Lawrence Erlbaum. 
Prager, K. J. (1995). The psychology of intimacy. New York: Guilford.

Reis, H. T., \& Patrick, B. C. (1996). Attachement and intimacy: Component processes. In E. T. Higgins, \& A. Kruklanski (Eds.), Social psychology: Handbook of basic principles (pp. 523-563). New York: Guilford.

Roberts, M. C., Brown, K. J., Johnson, R. J., \& Reinke, J. (2005). Positive psychology for children: Development, prevention, and promotion. In C. R. Snyder, \& S. J. Lopez (Eds.), Handbook of positive psychology (pp. 663-686). Oxford: University Press.

Rockhill, C. M., Fan, M. Y., Katon, W. J., McCauley, E., Crick, N. R., \& Pleck, J. H. (2007). Friendship interactions in children with and without depressive symptoms: Observation of emotion during game-playing interactions and post-game evaluations. Journal of Abnormal Child Psychology, 35, 429-441.

Rose, A. J. (2007). Structure, content, and socioemotional correlates of girls' and boys' friendships. Merrill-Palmer Quarterly, 53(3), 489-506.

Rubin, K. H., Bukowski, W., \& Parker, J. G. (1998). Peer interactions, relationships and groups. In W. Damon (Ed.), Handbook of child psychology (pp. 619-700). USA: Wiley \& Sons.

Rusbult, C. E., Arriaga, X. B., \& Agnew, C. R. (2003). Interdependence in close relationships. In G. J. O. Fletcher, \& M. S. Clark (Eds.), Handbook of social psychology: Interpersonal processes (pp. 359-387). Oxford: Blackwell.

Seligman, M. E. P. (2002). Authentic happiness: Using the new positive psychology to realise your potential for lasting fulfilment. New York: Free Press.

Seligman, M. E. P. (2005). Positive psychology, positive prevention, and positive therapy. In C. R. Snyder, \& S. J. Lopez (Eds.), Handbook of positive psychology (pp. 3-9). Oxford: University Press.

Siegel, L. J. (1992). Overview. In A. M. La Greca, L. J. Siegel, J. L. Wallander, \& C. E. Walker (Eds.), Stress and coping in child health (pp. 3-6). New York: Guilford.

Siemer, M., Mauss, I., \& Gross, J. (2007). Same situation-different emotions: How appraisals shape our emotions. Emotion, 7, 592-600.

Smith, C. A., \& Kirby, L. D. (2000). Consequences require antecedents: Toward a process model of emotion elicitation. In J. Forgas (Ed.), Feeling and thinking: The role of affect in social cognition (pp. 83-106). New York: Cambridge University Press.

Smith, C. A., \& Lazarus, R. S. (1990). Emotions and adaptation. In L. A. Pervin (Ed.), Handbook of personality: Theory and research (pp. 609-637). New York: Guilford.

Snyder, C. R. (2000). Handbook of hope. Orlando, F. L.: Academic press.

Stephanou, G. (2004). School learning and achievement as social activities: The role of the interpersonal relationships and the subsequent emotions in academic achievement. In N. P. Terzis (Ed.), Proceedings of the 5th International Congress of Balkan Society for Pedagogy and Education: Quality in Education in the Balkans (pp. 195-203). Thessaloniki: Kyriakidis Brothers s.a.

Stephanou, G. (2005). Academic performance and interpersonal relationships (in Greek). In F. Vlachos, F. Bonoti, P. Metallidou, I. Dermitzaki, \& A. Efklides (Eds.), Human behavior and learning: Scientific annals of the psychological society of Northern Greece (Vol. 3, pp. 201-228). Athens: Ellinika Grammata.

Stephanou, G. (2007). Students' appraisals and emotions for interpersonal relationships with teachers. In S. Vosniadou, D. Kayser, \& A. Protopapas (Eds.), Proceedings of the European Cognitive Science Conference (pp. 568-574). Canada: Lawrence Erlibaum Associates.

Stephanou, G. (2008). Students' value beliefs, performance expectations and school performance: The effect of school subject and gender. Hellenic Journal of Psychology: The Journal of the Psychological Society of Northern Greece, 5, 231-257.

Stephanou, G. (2010, December). Children's hope, attributions and emotions for their friendships. In G. Stephanou (Ed.), Invited symposium children and youth interpersonal relationships: Socio-cognitive factors and emotional experience. 3rd International Conference of the Psychological Society of Northern Greece: Children and Youth in Changing Societies. Thessaloniki, Greece.

Stephanou, G. (2011). Children friendship: The role of hope in attributions, emotions and expectations. Psychology, 2(8), 875-888.

Trope, Y., \& Gaunt, R. (2005). Attribution and person perception. In M. A. Hogg, \& J. Cooper (Eds.), Handbook of social psychology (pp. 190-208). London: Sage.

Underwood, M., \& Hurley, J. (1999). Emotion regulation and peer relationships during the middle childhood years. Child Development, 63, 366-380.

Vandell, D. L., Nenide, L., \& Van Winkle, S. J. (2007). Peer relationships in early childhood. In K. McCartney, \& D. Phillips (Eds.), The blackwell handbook of early childhood development. New York: Blackwell.

Weiner, B. (1992). Human motivation: Metaphors, theories and research. London: Sage. 
Weiner, B. (1995). Judgments of responsibility: A foundation for a theory of social conduct. New York: Guilford.

Weiner, B. (2001). Intrapersonal and interpersonal theories of motivation from an attributional perspective. Educational Psychology Review, 12, 1-14.

Weiner, B. (2002). Social emotions and personality inferences: A Scaffold for a new direction in the study of achievement motivation. Key Speech at the 8th WATM \& Motivation and Emotion Conference. Moscow, Russia.

Weiner, B. (2005). Motivation from an attribution perspective and the social psychology of perceived competence. In A. J. Elliot, \& Dweck, C. S. (Eds.), Handbook of competence and motivation (pp. 73-84). New York: Guilford.

Weiner, B. (2006). Social motivation, justice, and the moral emotions: An attributional approach. Mahwah, N. J: Erlbaum.

Weiner, B., \& Handel, S. (1985). Anticipated emotional consequences of causal communications and reported communication strategy. Developmental Psychology, 21, 102-107.

Williams, B., \& Gilmore, J. (2008). Annotation: Sociometry and peer relationships. Journal of Child Psychology and Psychiatric, 35, 997-1013.

Ybarra, O., \& Stephan, W. G. (1999). Attributional orientation and the prediction of behavior: The attribution-prediction bias. Journal of Personality and Social Psychology, 76, 718-727. 